\title{
Indigenous Breeds of Cattle, their Productivity, Economic and Cultural Values in Sub-Saharan Africa: A Review
}

\author{
Kubkomawa, H. I. \\ Department of Animal Production and Health, Federal Polytechnic, Pmb 35, Mubi, Adamawa State, \\ Nigeria \\ kubkomawa@yahoo.com
}

\begin{abstract}
The objective of the study is to have a critical review on how indigenous breeds of cattle, their productivity, economic and cultural values affect Nigerians. Present cattle population in Nigeria has been estimated as 15.3 million and breeds of cattle indigenous to Nigeria include White Fulani, Red Bororo, Sokoto Gudali, Adamawa Gudali, Wadara, Azawak, Muturu, Keteku, Ndama and Kuri. A recent survey of pastoralist households in Nigeria revealed that, the pastoralist herd size ranged from 16 to 69 cattle per herd and to maintain a calving interval of 365 days, a cow must re-breed in 80 to 85 days after calving. Cattle singly contribute about $12.7 \%$ of the agricultural Gross Domestic Product (GDP) in Nigeria. The cattle industry provides a means of livelihood for a significant proportion of pastoral households and participants in the cattle value chain in the sub-humid and semi-arid ecological zones of Nigeria. Thus, thousands of Nigerians make daily living from the sale, transport, processing and marketing of pastoral livestock products, including meat, milk, skins and draught power. Some research findings revealed that, the Nigerian cattle industry generates USD 6.8 billion of a potential USD 20 billion annually. Other cultural and economic contributions of cattle include the prestige inherent in their ownership and their place in custom, religion and festive occasions. Recently, cattle have been used as experimental animals such that much of what is known today about milk fat synthesis and the physiological mechanism that is involved, relate to the ruminant on account of its convenience in research.
\end{abstract}

Keywords: Indigenous Breeds, Cattle, Productivity, Economic, Cultural Values, Nigeria.

\section{INTRODUCTION}

Cattle command a prominent position in our meat supply and livestock industry. Beef is estimated to supply about 45 percent of total meat consumed in Nigeria, while the next in rank is sheep and goat meat with 35 percent. Our National herd contains an estimated 9.2 million herds of cattle in 1981. Over 90 percent of these are in the hands of traditional producers and in the Northern parts of the country (Ken, 1982). The growth rate in the national herd is estimated at 1.5 percent annually. It is interesting to note that, although developing countries contain about two-thirds of the World Cattle Population, about two-thirds of total beef production is accounted for by developed countries (Rimi, 1982). Whatever their level of production, livestock in developing countries provide millions of families with better nutrition, family income and employment opportunities, draft power and a more balanced agriculture. The objective of the study is to have a critical review on how indigenous breeds of cattle, their productivity, economic and cultural values affect Nigerians.

\section{Cattle Population, BReed and Distribution in Nigeria}

Presently, cattle population in Nigeria has been estimated as 15.3 million (Umar, 2007; Umar et al., 2008; Tibi \& Aphunu, 2010). There are many breeds of cattle indigenous to Nigeria. According to Pagot (1992); Babayemi, Abu, and Opakunbi (2014), the popular breeds of cattle in Nigeria include White Fulani, Red Bororo, Sokoto Gudali, Adamawa Gudali, Wadara, Azawak, Muturu, Keteku, Ndama and Kuri.

(i) White Fulani (Bunaji): White Fulani is the most numerous and widespread of all Nigerian cattle breeds (Blench, 1993; Meghen, MacHugh, Sauveroche, Kana, \& Bradley, 1999). The Nigerian National Livestock Research Survey (NNLRS) 1999; Alphonsus, Akpa, Barje, Finangwai and Adamu (2012) estimated that, the white Fulani represents $37 \%$ of the national herd. They are found from 
Lagos to Sokoto, Katsina and Kano States and spread across the Nigerian Middle Belt. The only areas from which they are significantly absent are Borno, where Rahaji and Wadara predominate, and in the south-east, where there are no resident Zebu. The movement of cattle into the derived savannah and to the edge of the humid zone has largely been of Bunaji and pastoralists generally agree that, they are superior to all other breeds of Zebu in resisting diseases with the ability to thrive under a variety of conditions (Blench, 1993; Meghen et al., 1999). The main limiting factors of this tropical breed of cattle include late sexual maturity, long interval between calving and short lactation length.

The White Fulani cattle are, however, important for their genetic predisposition of hardiness, heat tolerance and adaptation to local conditions (Alphonsus et al., 2012). It has white coat color and it is fairly large, height about $130 \mathrm{~cm}$, bull weighs about $500 \mathrm{~kg}$ and cows $325 \mathrm{~kg}$. The hump is large and well developed, navel flab is small, horns are of medium length, up curving, and lyre shaped. The White Fulani is a triple-purpose animal, with milk production of 2,300 $\mathrm{kg}$ per lactation. It may be fattened for beef, kept for milk production, or used as draught animal, especially the bull. Crosses of White Fulani and Holstein recorded increased milk production at NAPRI-Shika, Zaria (Alphonsus et al., 2012). Age at first calving was 42 - 45 months but in Fulani herds it can be as high as 5 years. They provide much of the beef consumed throughout Nigeria (Payne \& Wilson, 1999; Alphonsus et al., 2012).

(ii) Red Bororo (Rahaji): The Red Bororo is the third most numerous breed of cattle in Nigeria, representing $22 \%$ of the national herd. The Rahaji is adapted to arid and semi-arid regions and are rarely found further south than Kaduna in the wet season, except for the isolated population on the Mambila Plateau in the North-East (Blench, 1993; Meghen et al., 1999). The Rahaji is one of the largest Zebu breeds and is distinguished by its deep burgundy-colored coat, pendulous ears and long, thick horns (Katie \& Alistair, 1986; Williamson \& Payne, 1990). Fulani pastoralists consider the Rahaji an extremely prestigious breed and many herds of 'white' cattle include a few Rahaji for crossbreeding. Nonetheless, it tolerates neither humidity-related diseases nor poor nutrition (Blench, 1993). Strikingly, a Fulani clan, the Rahaji, named for the breed they traditionally herded, has been obliged to exchange their stock for Bunaji as they have moved south into the Middle Belt because of high mortality among the 'red' animals (Meghen et al., 1999).

(iii) Sokoto Gudali: The Nigerian National Livestock Research Survey (NNLRS) estimated that, Gudali represents 32\% of the national herd. There are two quite distinct types of Gudali in Nigeria: the Sokoto Gudali (Bokolooji) and the Adamawa Gudali. The Sokoto Gudali stereotypically occurs mainly in the North-West of Nigeria, but in reality, it is now distributed widely throughout the country (Katie \& Alistair, 1986; Williamson \& Payne, 1990; Payne \& Wilson, 1999). The Sokoto Gudali is a uniform cream, light grey or dun, the dewlap and skin folds are highly developed and the horns almost absent. The hair is short and the skin is thick and pigmented. The ears are pendulous and are useful milkers. Their milk yield at the National Animal Production Research Institute (NAPRI), Shika was higher than that of White Fulani (Payne \& Wilson, 1999; Alphonsus et al., 2012). It has a calving interval of 360 - 450 days. The udders in the female are well developed with good teats, hence they are regarded as indigenous dairy breed. At maturity, the female weighs an average of about 330 $\mathrm{kg}$, while the male weighs about $450 \mathrm{~kg}$. The female produces an average of $1,500 \mathrm{~kg}$ of milk per lactation (Payne \& Wilson, 1999).

(iv) Adamawa Gudali: The Adamawa Gudali, as its name implies, is restricted to Adamawa (Blench, 1993; Meghen et al., 1999). The NNLRS (1990) estimated that, Adamawa Gudali represents $2 \%$ of the national herd. At least two local types were originally recognized in Nigeria: the Banyo, with Rahaji blood and rather large horns, often with a white face and red eye patches, and the Yola, which has an admixture of Muturu (Gates, 1952). The Muturu element has been progressively diluted since the 1950s and the Yola breed is no longer recognized as a distinct variety by local herders. The Adamawa Gudali resembles the Bunaji in conformation. It is medium to large sized, with mediumlength horns and usually pied, or with a white, black, red or brown coat. It has thick, crescent-shaped horns, a pendulous hump, and a short head and muzzle (Katie \& Alistair, 1986; Williamson \& Payne, 1990), however, the pendulous hump is the feature that most reliably distinguishes it from the Bunaji. Both Kanuri and Fulani pastoralists own Adamawa Gudali cattle. It is rare for them to have complete herds of Adamawa Gudali, and often they are mixed with Wadara, Bunaji or Rahaji. Many farmers regard Adamawa Gudali as the indigenous race of the region and they are common in villages, where they are favored for ploughing, but when they become too large to pull a plough effectively, they are further fattened in the compound and sent to market (Payne \& Wilson, 1999; Babayemi et al., 2014). 
(v) Wadara: Wadara cattle, another Nigerian breed, are medium-sized, lightly built cattle, and are usually dark-red, black, pied or brown. They are short horned and have a small erect hump, representing some $6.6 \%$ of the national herd. Wadara cattle are the 'indigenous' cattle of Borno and are referred to by the Koyam and related pastoralists as 'our' cattle. They are frequently called 'Shuwa' in the literature, after the Shuwa Arabs who, also, herd them. A related breed with a white coat, the Ambala, is often traded into Nigeria from Chad (Blench, 1993; Meghen et al., 1999).

(vi) Azawak: The Azawak is another breed found in Nigeria and is said to be native to the Azawak valley North-East of Nigeria and is distributed along its North-Western border. It is lightly built with medium-length horns. Although Azawak in Niger Republic is commonly described as red, the Azawak that enter Nigeria are usually a light fawn color, though they can also be white, brown, pied and black. The NNLRS (1990) estimated that, they represent just $0.7 \%$ of the national herd. A small population of Azawak cattle exists in Nigeria throughout the year, but the majority is seasonally transhumant. Azawak are generally only found on the border North and West of Sokoto but there are, also, some in the North-West of Borgu and dotted along the frontier from Sokoto to Katsina (Blench, 1993; Meghen et al., 1999).

(vii) Muturu: The West African dwarf short-horn or Muturu is small bodied, and blocky in conformation with short, fine-boned limbs. It has a compact body, no hump, a straight back, and a broad head. The face is slightly dished, and the horns are very short. In South-Central Nigeria, the Muturu is generally black, or black and white. The Muturu on the Jos Plateau itself are usually black and white but are distinctly larger than the low-land animals. There are more variations in the Northern populations; where brown, red or tawny animals are recorded. Within Nigeria, Muturu cattle have a very disjointed distribution, suggesting, a gradual retreat of a once more widespread population (Payne \& Wilson, 1999; Blench, De Jode, Gherzi, \& Di Domenico, 1998).

Blench et al. (1998) have reviewed the history, distribution, management and productivity of the Muturu. Inadequate maps of their distribution have seriously marred numerical estimates of the numbers of Muturu. Muturu are widely dispersed and often stall-fed, and so are less visible than Zebu. As a result, published population figures are little more than informed guesses. Moreover, since Northern Muturu are barely known and their trypano-tolerance is unmeasured, they have usually been excluded from estimates of 'trypano-tolerant' cattle. ILCA's (1979) estimate of 120,000 Muturu should be contrasted with that of Ngere (1983), who gave a figure of 60,000 or $0.7 \%$ of the national herd. Akinwumi and Ikpi (1985), surveying five states in the south, reported 85,000. The NNLRS (1990), the first survey to consider all the population islands, gave an estimate of some 115,000 for 1990 (RIM, 1992).

There are isolated populations of Muturu along the Republic of Cameroon frontier up as far as SouthEastern Borno, adjoining the Michika-Mubi area of Adamawa. Small clusters exist in the Atlantika mountains, South-East of Yola and near Cham, east of Bauchi. Muturu are still relatively common in South-East of the Jos Plateau in the dry savannah (Blench, 1993; Meghen et al., 1999). There is another nucleus of Muturu north of Tegina in the North-West, with diverse coat-colors suggesting a link with the North-Eastern populations. Muturu were probably once kept throughout the whole of Southern Nigeria and their disappearance from many areas is relatively recent. West of the River Niger, Muturu were once widespread but are now uncommon. Both Keteku and Zebu have replaced them, or communities have ceased keeping them. At present, the major concentrations of Muturu are in the South-East, in the Cross River area and among the Tiv people in and around Makurdi. Muturu are kept throughout the Igbo areas but in very low densities (Blench, 1993; Meghen et al., 1999).

(viii) Keteku: The distribution and productivity of Keteku cattle have been studied in more detail by Blench et al. (1998). The definition of Keteku has become more problematic in recent years with an increasing proportion of Zebu blood in 'Keteku' herds. As Fulani pastoral herds push even further south and increasingly inhabit regions previously restricted to trypano-tolerant stock, more Zebu stock are bought in for village herds. For example, the 'Biu', a Zebu x Savannah Muturu cross found near Biu in southern Borno and described in the literature (Gates, 1952), has effectively become submerged in the local Zebu gene pool. Thus, application of the name Keteku to an individual animal may reflect as much the owner's cultural background as its actual genetic composition. The population size given by ILCA (1979) was 180,000 Keteku in Nigeria. Keteku are significantly less common than previously thought and their distribution quite different. It is unlikely that, there are as many as 100,000 of all types. 
The Borgu Keteku, also, known as Kataku, Ketari, Borgu, Borgawa and Kaiama, is a trypano-tolerant, stabilized Muturu x Zebu cross (Gates, 1952). It combines Muturu and Bunaji features with white, grey and black types predominating, and more occasionally red and brown. The horns are long compared with the Muturu, but the hump smaller, and the legs shorter than the Bunaji. In Nigeria, Keteku herds are restricted to a narrow band along the Benin Republic border in the region usually known as 'Borgu'. Further east, Keteku are occasionally kept adjacent to villages in Northern Yoruba land. West African dwarf shorthorn was once common through this region and the Keteku fills the same niche (Blench, 1993; Meghen et al., 1999). Farmers who value their combination of size and trypano-tolerance, sometimes buy Keteku as investment stock in the Ondo area. Keteku were formerly distributed from breeding farms as part of livestock extension programmes and the Government Livestock Centre in Ado-Ekiti keeps a stock of Keteku (Blench, 1993; Meghen et al., 1999).

In contrast to other West African countries, there has been very little 'new' crossing of Zebu and Muturu in Southern Nigeria. In some ways, it is surprising that, the cross-breeding of Zebu and Muturu did not take place all along the line where the two types came into contact. Further East, among the Igbo, farmers tend to assume that, the two breeds are incompatible; and that, attempts at cross-breeding would conflict with religious strictures. The continuing genetic separation on the Jos Plateau probably reflects ethnic competition between the livestock farmers than animal production considerations (Blench, 1993; Meghen et al., 1999).

(ix) N'dama: N'dama cattle are native to Senegambia and adjacent parts in the West of West Africa (Starkey, 1984; Blench et al., 1998; Babayemi et al., 2014). They were first brought into Nigeria from Guinea in 1939 on an experimental basis, because they were trypano-tolerant and yet were larger than Muturu (Starkey, 1984; Blench et al., 1998). The N'dama has a medium-sized compact body with lyre-shaped black-tipped horns and no hump. There is a small dewlap in the male, but a fairly large head. Although those imported into Nigeria are generally light brown, there are black and pied animals in Guinea. N'dama cattle have been sold to farmers and pastoralists with a view to improving the resistance of local herds to trypanosomiasis. In most cases, herders cross them with Zebu and there are now few pure N'dama outside institutions, although some were recorded in Northern Yoruba land (Blench, 1993; Meghen et al., 1999).

(x) Kuri: The Kuri is a large-bodied humpless long-horn, whose exact historical origin is unknown (Blench, 1993; Meghen et al., 1999; Babayemi et al., 2014). The Kuri has distinctive, inflated, spongy horns unknown in any other breed and with a mean height of $1.5 \mathrm{~m}$, and weight up to $550 \mathrm{~kg}$. It is one of the largest breeds of African cattle. Kuri are noted for their extremely variable colors and their ability to thrive in semi aquatic conditions. The nucleus of the Kuri cattle population is within the region of the former Lake Chad, and along its eastern shores. In Nigeria, Kuri are found not only on the Lake but on its shores and along the Yobe valley, as far west as Gashagar. There is, also, a restricted export of the Kuri as traction animals to the region North-East of Kano. The breeds along the Komadugu Yobe are crossed with the Zebu and are generally referred to as Jetkoram in the literature (Blench, 1993; Meghen et al., 1999).

\section{Cattle Herd Size and Productivity in Nigeria}

(a) Herd size: Optimum herd size for an area and for a population can only be estimated after many variables have been considered (Akpa, Alphonsus, \& Abdulkareem, 2012). A theoretical concept of optimum herd size takes account of the prevailing environmental conditions, biological capacity (performance) of the species, herd management practice, and resource use and distribution (Iro, 2009). For the pastoral Fulani of Northern Nigeria, none of these factors are static; therefore, optimum herd size is dynamic, varying by a wide margin, depending on the circumstance of the individual pastoralist.

Cunnings (1966), earlier found 100 - 150 as optimum Fulani cattle herd size, while Iro (1994) reported Fulani cattle herd size to be 80 - 100. In a related study, Adisa and Badmos (2009) reported an average cattle herd size of 41, while majority of herdsmen (46.4\%) herded 41 - 60 cattle. A recent survey of pastoralist households by Akpa et al. (2012) in Zaria and environs revealed that, the pastoralist herd size ranged from 16 to 69 cattle per herd. Also Okoli, Enyinnia, Elijah, Omede, and Unamba-Opara (2012) reported that, majority of Fulani pastoralist $(63.60 \%)$ maintained herd size of 41 to 70 heads in the humid rain forest of Imo State, Nigeria. Nigeria with a population of over 170 million people requires several heads of cattle to satisfy its demand for cattle and cattle products. With 
more than $80 \%$ of the cattle population in the hands of traditional pastoralists, the supply cannot match the demand. In an effort to bridge the gap, cattle importation is practiced. The imported figures, as at January 1996, were 5,142 heads per annum.

The pastoralist's operational sizes were examined in a study conducted by Usman and Nasiru (2005) to determine the composition of the herds in terms of steers, lactating cows, non-lactating cows and the calves. The pastoralists were grouped into three categories, namely small scale pastoralists (SSP), medium scale pastoralists (MSP) and large scale pastoralists (LSP). According to the study, the average herd size of the small scale pastoralists (SSP) was about 17 cattle, while that of MSP and LSP were 32 and 73 cattle, respectively. Also, the composition of their herd indicated that, LSP had more lactating and non-lactating cows as well as calves than the other groups of pastoralists, while the MSP excelled in the average number of steer in the herd (Mbap, 1996). An examination of stock composition in Zaria showed a gender imbalance, with a preponderance of the female stock than the males. On the average, the female species constituted 60 to $75 \%$ in each herd. The advantages of keeping more females in the herd are obvious. A simulation of herd dynamics proved that, the rate of growth of the herd peaks when female calves dominate the kraal (Iro, 2009). The young animals contributed about $50 \%$ of the herd size, with more females (35\%) than males (15\%). The proportion of breeding cows in the herd was $49.1 \%$, while the proportion of the breeding bulls was $6 \%$. The profitability of any cattle enterprise is highly determined by the number of breeding cows and young females in the herd (Whitley, 2008). This explains why the large proportion of the Fulani herd is composed of breeding cows and young females.

The males which were reasonably much in number at younger age but became fewer as they reached breeding age suggested that, bulls in the herd were sold out when they reached breeding age as a source of income to the family and only few were retained in the herd as breeding bulls. It is usually not economical to keep many bulls in the herd since one mature bull can service at least 20 cows in natural mating (Neumann, 1990). From these results, the number of cows and young animals in the herd were almost equal (0.98). The proportion of breeding bulls to young animals was small (0.14), which also gave an approximately equal proportion of breeding bulls to cows (0.15). The ratio of young males to females was 0.42 , indicating a higher number of young females than young males (Iro, 2009).

(b) Reproduction Performance: Reproduction is the most important factor in determining profitability in a cow/calf enterprise. To maintain a calving interval of 365 days, a cow must re-breed in 80 to 85 days after calving. Poor reproductive performance is directly linked to the percentage of body fat in cows. Researchers have determined that, a certain amount of body fat is required for the reproductive system to function, since inadequate nutrition is most often the cause of poor reproductive performance. Developing a nutrition program is easier and more cost effective when all cows on the farm can be managed in a similar manner. This is especially true when all cows on a farm are managed in a single herd, which is often the case with small production units (Babayemi et al., 2014).

Calving year round will make it very difficult to maintain adequate body condition on all cows at the critical times. Poor body condition is associated with reduced income per cow, increased post-partum interval, weak calves at birth, low quality and quantity of colostrum, reduced milk production, increased dystocia, and lower weaning weights. Increasing post-partum interval will result in a younger, smaller calf at weaning the next year and will result in lower incomes if sold at weaning. Weak calves at birth may not get adequate colostrum and are more susceptible to disease, reduced weaning weights, reduced feedlot performance and less desirable carcass traits. Research clearly shows that, cows in moderate body condition will have a shorter interval from calving to first estrus than cows in thin condition (Babayemi et al., 2014).

According to Okoli et al. (2012), 90.90\% of pastoralists in the humid rain-forest of Nigeria allowed $6-10$ calving per cow within its reproductive life, while a limited $9.10 \%$ may allow up to $11-15$ calving per cow. This implies that, most of the female animals culled for sale are very old animals, which is in agreement with the report of abattoir studies by Okoli, Ebere, Emenalom, Uchegbu, and Esonu (2001). Cattle production and breeding efficiency on grazing rangelands of Northern Nigeria is however low, especially during the dry season (Mapiye, Chimonyo, \& Dzama, 2009). For example, age at first calving and calving interval for cows exceed two years (Nqeno, Chimonyo, Mapiye, \& 
Marufu, 2009), steers reach slaughter weight between 24 and 30 months of age (du Plessis \& Hoffman, 2004) and off-take rates vary between 2 and 10\% per annum (Mapiye et al., 2009). According to Akpa et al. (2012), the average age at first calving of the breeding cows was 4.75 years. This agreed with data earlier obtained from Bunaji herds on the Jos Plateau (Synge, 1980), but higher than the 37-month reported in Government Farm at the National Veterinary Research Institute, Vom (Ologun, 1980). This variation is mainly attributed to low feed quantity and quality on communal grazing lands, particularly during the dry season (Angassa \& Oba, 2007; Nqeno et al., 2009). Under such conditions, provision of feed supplements could be recommended to improve cattle production. Before any nutritional improvements are recommended, it is however, important to identify the types of nutrients limiting cattle production in a given zone (Ndlovu, Chimonyo, \& Muchenje, 2009).

Akpa et al. (2012), also, reported that, bulls in the pastoral cattle herds usually reached considerable average age of 4.05 years before breeding. This could be probably due to poor nutrition and other environmental stressors. Blezinger (2008), reported that, nutrition and feed intake of young bulls affect the age at which they reach puberty. However, Neumann (1990), suggested that, bull calf of about 15 months of age should not be allowed to run with the cows, where controlled breeding is being practiced. Standard technical coefficients have been used to compare between what is obtainable in the research institution like National Animal Production Research Institute, Zaria or National Veterinary Research Institute, Vom and that prevailing under the traditional system in Nigeria (Mbap, 1996). The information collected were on calving rate, calving cycle, age at first calving, length of lactation, productive life and milk to butter ratio. These were found to be $3-4$ years, 13 months (Pregnancy 9 months with 3 months resting period), 38 months, 280 - 300 days, about 10 years of age (ie. 5 - 6 lactation plus 4 years before lactation) and lastly the milk to butter ratio of 1 litre to $100 \mathrm{gm}$. In comparison with the above, the calving cycle in Nigeria ranges from 29 to about 43 months. The age at first calving ranges between 30 to 42 months, while the productive life ranges between 9 and 14 years (Mbap, 1996).

(c) Productivity: Protein, energy and minerals are the most critical nutrients affecting milk and beef production in the semi-arid areas (Devendra \& Sevilla, 2002). Some reports have suggested that, energy and minerals are not limiting nutrients to grazing cattle, but attributed losses in cattle productivity to deficiencies in protein (Tainton, 1999; Chimonyo, Kusina, Hamudikuwanda, \& Nyoni, 2000). Poppi and McLennan (1995) and Devendra and Sevilla (2002), however, reported that, during the early to mid-wet season, rangelands are not adequate sources of energy and minerals. This results in low cattle growth rates during this period and stands as a major constraint to increasing body weight gains (Shabi et al., 1998; DelCurto, Hess, Huston, \& Olson, 2000) and consequently affecting beef production in the semi-arid areas. Generally, rangeland energy and mineral supplies in the late wet and dry seasons are arguably deemed to be sufficient to meet production requirements of cattle on pastoral system in the semi-arid areas (Poppi \& McLennan, 1995; Chimonyo et al., 2000). Thus, cattle production efficiency on communal rangelands in the semi-arid areas is often determined by nutrient availability, which in turn, is mainly influenced by temperature and seasonal distribution of rainfall (Angassa \& Oba, 2007).

The traditional cattle sector in Nigeria is generally characterized by low productivity occasioned by seasonality of quantitative and qualitative feed shortage, which is perhaps the major constraint to improved production and productivity of smallholder enterprises (Olaloku \& Debre, 1992; Barje, Adebayo, \& Lamidi, 2011). However, by extensive spatial grazing, the pastoralists optimize spatial resource use, allow the soil to rejuvenate, and prevent permanent land damage. The impact of seasonal variation in feed resources on the condition and performance of cattle grazing the Guinea Savannah Zone of Nigeria has not been fully established. Such information is critical in developing appropriate feeding and disease prevention strategies. For example, the abrupt diet change that cattle experience from one season to another leaves them prone to digestive upset (Barje, Adebayo, \& Lamidi, 2011). Although the switch from a forage diet to a finishing diet high in grain gives beef its desired marble characteristic, it also upsets the animals' digestive system, which can adversely impact their growth. Similarly, marked seasonal quantity and quality of feed resources supplied affect their performance and carcass quality (Barje et al., 2011).

\section{ECONOMIC AND CULTURAL IMPORTANCE OF CATTLE}

Nigeria is one of the leading countries in cattle production in sub-Saharan Africa. For example, in 2008, Tibi and Aphunu (2010) reported that, the country had over 14.73 million cattle consisting of 
1.47 million milking cows and 13.26 million beef cattle. Less than $1 \%$ of this population is managed commercially, while about $99 \%$ is managed traditionally. Under the traditional system, there is the use of indigenous methods in all aspects of cattle production including health management (Mafimisebi et al., 2012). This tilt towards traditional management continues to have grave implications for commercialization of the production of cattle and cattle products and their prices in Nigeria (Abubakar \& Garba, 2004).

Cattle singly contribute about $12.7 \%$ of the agricultural Gross Domestic Product (GDP) in Nigeria (CBN, 1999). The cattle industry provides a means of livelihood for a significant proportion of pastoral households and participants in the cattle value chain in the sub-humid and semi-arid ecological zones of Nigeria (Adegeye, 1995; Okunmadewa, 1999; FAO, 2006). Thus, thousands of Nigerians make daily living from the sale, transport, processing and marketing of pastoral livestock products, including meat, milk, skins and draught power. Some research findings revealed that, the Nigerian cattle industry generates USD 6.8 billion of a potential USD 20 billion annually (Bénard, Bonnet, \& Guivert, 2010). The cattle industry, also, contributed 3.2 to $4 \%$ to overall GDP of the country (FAO, 1999; CBN, 1999; Mbanasor, 2000; Ifeanyi, \& Olayode, 2008). Although, there are many sources of animal protein in Nigeria, several studies have shown that, cattle and their products are the predominant and the most commonly consumed animal protein sources. Thus, cattle are a highly valued livestock in Nigeria and are kept for beef, hides and milk or for traction (Tukur, \& Maigandi, 1999). Among pastoralist, however, cattle are kept as a status symbol and cultural medium, while in other cultures it, also, plays a major role in marriages, weddings, sacrifices, and funerals (Tibi, \& Aphunu, 2010). From the foregoing, it is obvious why cattle production and marketing are notable employment and income-generating livelihood activities for many Nigerians.

Furthermore, cattle are sources of raw materials such as bones, wool, fur, hides and skin, milk etc. for the production of clothing and leather products such as foot wears like shoes, belts, bags, shawl and milk products such as yoghurt, butter and cheese. Oxen are, also, used as draught animals for transportation and land cultivation (Payne \& Wilson, 1999; Kubkomawa, Helen, Timon, Kabir, \& Neils, 2011). Cattle are a very important source of farm power in Nigeria and in different parts of the world, since it is accessible to peasant farmers who cannot afford costly mechanized farm power (Jahake, 1992). Draught animal power is widely used for cultivation, transportation, water lifting and powering food processing equipment and has enhanced the volume of crop production in areas of use (Kubkomawa et al., 2011; Babayemi et al., 2014). For example, according to FAO (1996), where cattle are used to graze the vegetation under plantations of coconut, oil palm and rubber in Malaysia, it dramatically reduces the cost of weed control sometimes by as much as forty percent. Again, according to FAO (1997), cow dung is highly valued for cooking and heating in many countries. For example, $25 \mathrm{~kg}$ of fresh cow dung could be used to produce one cubic meter of biogas, which can be used to provide energy for light, heat or motive power. Cattle, also, serve as means of foreign exchange earnings, for instance, beef, milk, hides, skin and other by-products are exported to earn foreign currency (Payne \& Wilson, 1999). In Nigeria, cattle are kept at subsistence level by a farmer and usually serve as the first step out of poverty by rural dwellers. Thus, to the traditional arable farmer, cattle offers security of continued food supply during periods of crop failure.

Other cultural and economic contributions of cattle include the prestige inherent in their ownership and their place in custom, religion and festive occasions. Recently, cattle have been used as experimental animals such that much of what is known today about milk fat synthesis and the physiological mechanism that is involved, relate to the ruminant on account of its convenience in research. Cattle, also, assist in the economic utilization of non-marketable crop resources, adding to them. These animals are able to survive on fallow lands and others that are not good for arable crop farming, thereby maximizing the use of the available land resource. They are, also, used as gifts or for payment of bride price in traditional rites where they serves as family wealth (Payne \& Wilson, 1999).

Cattle as well as other animals provide organic manure which improves soil fertility. Farm manure which consists of animal fecal materials is used to fertilize farm lands. Manure itself is a valuable fertilizer containing $8 \mathrm{~kg}$ of nitrogen, $4 \mathrm{~kg}$ of phosphorus and $16 \mathrm{~kg}$ of potassium to the tone (FAO, 1999). Adding manure to the soil not only fertilizes it but, also, improves its structure and water retention capacity. Bulls can, also, be used as game animals and may be source of prestige to farmers kept at recreational parks for tourism activities. It represents the position of the owner and the family 
in the society. Overall, cattle are seen as a measure of status of the owner in the society, as mobile banks by nomads, as insurance against crop failure by mixed farm producers and as items of religious worship and marriages by various groups of traditionalists (Payne \& Wilson, 1999).

\section{Cattle Products and By-Products}

Cattle have been used as a major animal protein sources in many cultures with its by-products representing $66.0 \%$ of its live weights and $11.4 \%$ of the gross income (Liu, 2009). About $99 \%$ of global cattle are utilized for meat and other products such as hides and skins which are processed into leather before being used (Liu, 2009; AFRIS, 2010). Animal hides have, also, been used for shelter, clothing and as containers since pre-historic times. Hides and skins are generally one of the most valuable by-products from animals.

Animal fats are important by-products of meat packaging industry. The major edible animal fats are lard and tallow. Animal fats are used together with molasses to improve palatability and energy value of feeds (AFRIS, 2010). They are, also, used to control dustiness in feed. A lot of fat from cattle are used in cosmetics, especially in the manufacture of lipstick and eye make-up, soap, lubricants, hair sprays, conditioners, deodorants and creams (Gandhi, 2009). Tallow is, also, used in steel rolling industry to provide lubrication and also in some leather conditioners. The leather meals may also be hydrolyzed the same way as feathers (Gohl, 1981). Leather is composed primarily of collagen, a fibrous protein which has a poor amino acid profile. Leather scraps associated with the production of various leather products can be collected and hydrolyzed in a similar manner as poultry feathers and used as supplemental protein for livestock (AFRIS, 2010). Hydrolyzed leather meal has been shown to be an acceptable source of crude protein for ruminants at levels not exceeding $6 \%$ of the diet (Knowlton, Hoover, Sniffen, Thompson, \& Belyea, 1976). Gohl (1981) reported that, hydrolyzed leather meal can be included in broiler and pig diets at levels of up to 8 and $13 \%$ respectively, with no adverse effect.

The digestibility of horns and hooves meal has, also, been shown to increase progressively with fineness of the ground materials (Gohl, 1981). Horn and hoof meal contain crude protein (69.5 to $88.6 \%$ ), ash (5.6 to $15.8 \%$ ) and ether extract (4.7 to 14.7\%). The protein is mainly keratin and other proteins. Horns and hoof meals have been used at low levels in poultry diets with variable results and it seems to be unpalatable to most classes of livestock (Gohl, 1981; Babayemi et al., 2014). A high digestibility of about $80 \%$ for crude protein has been reported for horn and hoof meal prepared by steeping the hoofs and horn in $10 \%$ sodium carbonate for sixty hours at $20^{\circ} \mathrm{C}$, after which the material is boiled in water for one hour and dried at a high temperature until it turned golden yellow (AFRIS, 2010).

Gelatin is the product of connective tissues of beef animal. Other products that contain gelatin might include gum, fruit snacks like gummy bears, and marsh mallows and many medical products (Liu, 2009). In the past, many beef by-products were favorite foods in Asia, but health concerns have led to increased focus on non-food uses such as pet foods and pharmaceuticals such as anti-rejection drugs used during organ transplant to help the body accept the new organ. Other medical uses such as insulin in diabetic patients and the sticky part of bandages are made from animal insulin and fatty acids, respectively (Liu, 2009). In developed countries, animal by-products from the slaughter house may include meat trimmings, inedible parts, organs, fetuses and certain condemned carcasses but not including blood, hair, hooves, horns, manure and stomach content, and hide trimmings (Miles \& Jacob, 2009). Some of these however, form edible parts in many developing countries.

Olomu (1995) reported that, meat meal is, almost, similar to meat and bone meal except that, it guaranteed low phosphorus to show that little or no bone was added. Meat meals are widely used in feeds for poultry and pigs. They are usually too expensive to feed to ruminants, which in any case generally find meat products unpalatable. Because of the high price of meat meal, they are used to balance the amino acid composition of diets rather than as major source of protein (Gohl, 1981). Normally, less than 5\% meat meal are used in growing and finishing diet for pigs and less than 10\% in the diet for piglets and poultry. The product is, also, a good source of lysine but it is somewhat deficient in methionine, cystine and tryptophan (Olomu, 1995). The protein quality is lower than fish meal or soya bean meal for application in feeding swine or poultry when used to supplement crude protein in cereal based diets (AFRIS, 2010). 
Blood meal is high in protein (about 80\%) and energy, and can form an excellent source of lysine, if properly prepared. It is very rich in leucine but low in lsoleucine (Olomu, 1995). Blood meal is hydroscopic and need to be dried to less than $10-12 \%$ moisture and stored in a dry place. Combining blood meal with other supplemental protein sources was shown to improve performance in ducks (AFRIS, 2010). Blood meal is, also, used as fertilizer, but if over applied, it can burn plants with excessive ammonia. Liu (2009) reported that, blood could be used to produce edible products for human beings. For example, in Europe, animal blood has long been used to make blood sausages, blood pudding, biscuit and bread. Blood plasma has an excellent foaming capacity and can be used to replace egg white in the baking industries. Haem derived from animal blood is a valuable source of organic iron. Blood is, also, used in food as an emulsifier, stabilizer, a clarifier and color additive.

In the laboratory, many blood products such as plasma, albumen, globulin and fibrinogen are used as nutrient for tissue culture media, as necessary ingredient in blood agar and as peptone for microbial growth. Blood, also, has industrial uses, as an adhesive in the manufacture of paper, plywood, fibre, plastic and glue. Blood is used as sprays in insecticides and fungicides and as a stabilizer in cosmetics, and as a foaming agent in fire extinguishers. Similarly, USDA (1993) reported the uses of cattle blood in the manufacture of shoe polish and in the sizing of leather as well as in the making of calico printers, in fixing certain pigment colors in cloth. A blood substitute, called Hemopure has been developed by Biopure Corporation (Boston, MP) from an extract of cow's blood.

When ruminant animals are slaughtered, the contents of their rumen can become a valuable feed resource, which can be dried immediately in the sun and used to replace bran in poultry feed and can constitute up to $10 \%$ of the total ration (Williamson \& Payne, 1990). It can, also, be ensiled, but it needs to be mixed with a readily fermentable source of carbohydrates in order to be ensiled properly. It can, also, be mixed with blood for use in poultry feeding. Rumen content can serve as a good source of water-soluble vitamins, crude protein and dietary energy for herbivores (AFRIS, 2010). Only the content of the first three (3) stomachs are used for this purpose, while the content of the 4th stomach is a liquid and of low feeding value (Williamson \& Payne, 1990; Mohammed, Igwebuike, \& Kwari, 2005).

\section{Marketing OF CATtLe in Nigeria}

Marketing encompasses all business activities associated with the transfer of a product from the producers to the consumers (Kohls \& Uhls, 2002; Girei, Dire, \& Bello, 2013). In the case of cattle, it is concerned with the movement of cattle from the pastoralists in the production locations in Northern Nigeria to the final consumers who are resident in Southern Nigeria (Omoruyi et al., 2000). The cattle marketing process makes possible the delivery of cattle to the buyers in the form, place and time needed (Girei et al., 2013). This process of bringing the cattle from where they are surplus (production/origin areas) to where there are shortages (consumption/sink markets), a process known as arbitraging, needs to be fully understood to enhance the efficient working of cattle markets, which is vitally important in achieving sustainable and profitable agricultural commercialization in the livestock sub-sector in Nigeria (Mafimisebi, 2012). Marketing is an economic activity which stimulates further production and if efficiently done, both the producer and consumer get satisfied in the sense that the former gets a sufficiently remunerative price for the product to continue to produce, while the latter gets it at an affordable price that stimulates continued consumption (Umar, 2005).

Cattle and beef trade provides the largest market in Nigeria, with millions of Nigerians making their livelihood from various beef-related enterprises (Umar et al., 2008). Consequently, the outcome of enhanced production and marketing of cattle and its products carry the potentials to better the income and nutritional status of households and positively impinge on their living standards. Efficient marketing plays an important role in the attempt to achieve wider accessibility and affordability of any product to consumers (Mafimisebi, 2011). This is obvious from the long established truth that, production and marketing constitute a variety. Thus, lack of development in one will necessarily obstruct development in the other (Seperich, Woolverton, \& Beirlein, 2002)

Thus, the level of profit generated depends, to a greater extent, on how efficiently the market for a commodity works (Mafimisebi, 2012). The performance of a market is influenced by the structural characteristics of the market and the competitive behavior of actors in the marketing chain. Understanding how these factors work independently and together can provide a basis for identifying 
opportunities to be exploited and constraints that need to be removed for enhancement of commercialization. Gaining insights into how the cattle market works in Nigeria will, therefore, involve in-depth assessment of marketing efficiency in terms of the benefits derived by value chain participants and consumers (Babayemi et al., 2014).

According to the National Livestock Project Division (NLPD, 1992), the supply of cattle and its products has witnessed a decline, while the demand has been increasing with the result being a shortfall in the supply. The high cost of marketing cattle is often the commonly cited culprit for this situation. Owing to the considerable spatial separation of the production area from the consumption area and other ancillary factors, there is high handling cost, especially in relation to cattle transportation (Filani, 2006). Transportation of cattle from the North to the South in Nigeria presents a daunting challenge because it is both a costly and risky business. Cattle are kept standing and in some cases, lying on top of each other in the vehicles throughout the long journey of 2 - 3 days. Most rural roads are seasonal and un-operational during the rainy season, while some inter-state roads are, also, in bad shape. Therefore, trucks and vehicles are prone to accidents, while cattle and freight insurance is still unpopular among the generally semi-literate cattle rearers, middlemen and transporters. The possibility, also, exists of transporters and traders being robbed in transit (Filani, 2006).

Production without access to market has also been identified as a problem for many livestock producers in Nigeria (Mubi et al., 2012). Delgado et al. (1999), however, stated that, livestock revolution can be expected to allow the rural poor in developing countries to contribute to the growing market, but pastoral populations in Northern Nigeria lack reliable marketing outlets that could provide the full benefits of indigenous cattle resources to be captured by both pastoralists and pastoral production systems (Filani, 2006).

Marketing of cattle in Nigeria is an economic activity common to all the Northern pastoral regions and there are days designated for cattle marketing (Mubi et al., 2012). Many people who participate in the marketing activities depend on it as their source of income, and to satisfy the economic needs and wants of the practitioners (Agboola, 1979). From this point of view, cattle marketing can be said to be the performance of all business activities which directs the smooth flow of cattle to consumers from sellers in order to accomplish the producer's objective (Mubi et al., 2012; Girei et al., 2013). This has played a vital role in Nigeria in terms of economic, social and cultural contributions to the people involved in rearing and marketing of cattle as well as all tiers of Government (Mafimisebi, Bobola, \& Mafimisebi, 2013).

Marketing of cattle in Northern Nigeria is a function of so many factors among which are, transportation, pricing and financing, risk bearing and keeping of cattle for future marketing. Sixty percent of the marketable cattle crossing national boarders are destined to Nigeria (Von Kaufmann, 1986; Girei et al., 2013). More than half of the cattle traded are from neighboring Chad, Central Africa, Niger and Cameroon (Mubi et al., 2012). Large numbers of cattle, sheep and goats are imported as well as various milk products to a value of about two hundred and fifty million dollars in 2003 (FAO, 2006). As a result of this, there is need to tackle the problem of increase in demand for cattle products which will lead to increase in productivity and subsequently efficiency in marketing of cattle in Nigeria, just like other parts of the world (Mafimisebi et al., 2013).

The traders involved in selling and shipment of cattle are mostly men of varying ages. Mubi et al. (2012) reported that, $100 \%$ of cattle marketers in Adamawa were men because of the marketing tasks involved coupled with the fact that, the Northern muslims that form the largest population of the marketers do not allow their wives to go out for such business, as also reported by Auwal (2005). Mafimisebi et al. (2013) reported similarly that, $87 \%$ of cattle marketers were men in South-Western Nigeria. Mubi et al. (2012) observed that the marketers were in different age groups such as 30, 31 40 and 41 years and above as reported by Mafimisebi et al. (2013) in South-Western Nigeria. This implies that, both the young and the aged can successfully make marketing a business to live on, but the younger ones are more active than the aged and invariably more into the business (FAO, 1990). Mubi et al. (2012) reported that, $66 \%$ of cattle marketers were married which supports a similar result obtained by Kohls and Uhls (1985). This implies that, marketing of cattle is a profitable venture that sustains individuals and families. They, also, reported that, minority of the marketers can read and write indicating that, they have attended secondary, tertiary or Qur'anic and primary education which was in contrast with Wakili (1996), who recorded least number of respondents with Quranic education and more attendance of post-primary. Their analysis indicates that, most of the marketers lack formal 
education which resulted in lack of proper keeping of records and poor communication during marketing, among others. This could affect efficient marketing activities since Schultz (1995), reported that, education enhances a person's ability to deal with economic disequilibria.

Mubi et al. (2012) reported that, majority of the cattle marketers have cattle marketing experience ranging from $1-40$ years experience. The retailer agents form $43 \%$, while the commission agents and wholesalers form 21 and 36\%, respectively. Ajiya (1998) revealed that, insufficient capital by other commissioned agents is as a result of not being in the business for a long time, therefore, they are not well established. Mubi et al. (2012), reported factors considered in attracting higher prices to include size and conformation of the animal, sex, color and health of the animal. The sources of capital to start the business of cattle marketing is another important issue to be considered. This is because, the source and capital base of the business determines the state of the business. Mubi et al. (2012) reported that, $40 \%$ of the marketers obtained their capital from relatives and friends, $28 \%$ from banks, $27 \%$ from fellow traders, while $5 \%$ of the capital came from other sources.

\section{COST AND Returns In CATTLE MARKeting}

There is no fixed cost and returns item because traders did not own either a ware house or a truck. Most of their expenses are restricted to the operational costs of maintaining the animals in terms of supplementary feedings before final conveyance to the distant markets as well as taxes/levies paid in transit and thus, only gross margin could be calculated. According to Adegeye and Dittoh (1985), gross margin is a good measure of profitability. The budgeting model is based on the average values reported by all the marketers in each category. Research has showed that, all the various categories of marketers are able to cover their total variable cost of marketing and earn a reasonable level of returns. The variable costs included labor, feeding, water, transportation, veterinary services, association fees, taxes and loading and unloading charges. The average cost price per head of cattle is $\mathrm{N} \mathrm{69,000,} \mathrm{N} \mathrm{78,600} \mathrm{and} \mathrm{N} \mathrm{82,300} \mathrm{for} \mathrm{cattle} \mathrm{dealers,} \mathrm{retailers} \mathrm{and} \mathrm{brokers,} \mathrm{respectively,} \mathrm{while} \mathrm{the}$

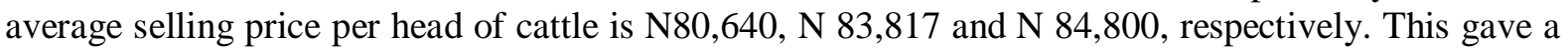
gross margin of $\mathrm{N} \mathrm{6,548,} \mathrm{N} 4,655$ and $\mathrm{N} 2,342.5$ per head of cattle for a dealer, retailer and broker, respectively (Mafimisebi et al., 2013).

\section{Profitability and EfFiciency Ratios of Cattle Marketing}

According to Mafimisebi et al. (2013), a profitability ratio of $0.09,0.07$ and 0.03 was reported for dealers, retailers and brokers, respectively. This shows that, the cattle marketing business is profitable to the different category of marketers in Nigerian markets. Another interesting observation was that, profitability was highest among the cattle dealers closely followed by the retailers while the brokers had the lowest profitability ratio. This might not be unconnected with the distance covered in transportation by the cattle marketers as transportation was the major value-adding activity in cattle marketing. Thus, findings from their study seem to suggest that, the greater the distance covered to source cattle by an intermediary, the higher the profitability ratio. An enterprise is regarded as operationally efficient or inefficient as the efficiency ratios is greater than one or less than one, respectively. In this case, efficiency ratios of $1.09,1.07$ and 1.03 was indicated for dealers, retailers and brokers, respectively. This shows that, the marketing enterprise was operationally efficient at the different marketer categories with the cattle dealers being the most operationally efficient closely followed by the retailers and the brokers.

\section{DEMAND AND SUPPLY OF BEEF}

At present, the Fulanis provide over 85 percent of Nigerian meat supplies. However, their nomadic system of production is increasingly coming under pressure from rapidly changing social, economic and political situations as Nigeria develops. For example, the proliferation of states, opening of huge areas of land by River Basin Development Authorities for irrigated agriculture, the development of new cities like Abuja, the new Federal Capital, and the land use Act which failed to recognized the rights of the Fulani herdsmen to transient usage of land for grazing, all serve to make nomadism increasingly untenable as a method of cattle production.

Unfortunately, we do not have at present a viable alternative in place, as most government and private beef production projects, making use of modern methods, are yet to make an appreciable impact.

The national meat supply position is very critical. The situation appears to be deteriorating with time. But for the needed support given in the form of massive importation of meat and meat products in recent years, the national meat shortage situation would have attained acrisis dimension (Oyenuga, 
1982). Beef accounts for more than 50 percent of Nigeria's total meat supply. Although it has always been difficult to specify by number or by its proportion of the national herd, it is, nevertheless, known that, a significant portion of the locally produced beef derived from trade cattle from Nigeria's neighbors like Chad, Niger and Cameroon. This has significantly reduced the acute beef shortage that would have been experienced if Nigeria had relied entirely on her own resources for meat supply.

Nigeria with a population of over 180 million people requires several heads of cattle to satisfy its demand for cattle and cattle products. With more than $80 \%$ of the cattle population in the hands of traditional pastoralists, the supply cannot match the demand. In an effort to bridge the gap, cattle importation is used. The imported figures as at January 1996 was 5,142 heads (Usman, \& Nasiru, 2005), cattle off-take rate was estimated at $12 \%$ per annum starting from the base year. This was found to be 1,673,640 heads of cattle as at 1990, 1,759,091 for 2004 and is projected to be 1,769,672 by 2010. Furthermore, the beef equivalent per annum was also estimated. This was found to be $209,205,000 \mathrm{~kg}$ as at $1990,219,886,378 \mathrm{~kg}$ by 2004 and is expected to reach $221,208,999 \mathrm{~kg}$ by the year 2010. The low figures may be attributed to the slow growth rate, poor conception rate, delayed age at first calving, long calving interval and low carcass yield of our traditional breeds coupled with extensive traditional management.

According to Usman and Nasiru (2005), the average price trend of cattle in Northern Nigeria ranges from $\mathrm{N} 20,272$ to $\mathrm{N} 22,342$ for a steer, whereas that of a cow averages $\mathrm{N} 16,206$ and N19,773 by January to December, 1996, respectively. As at 2005 the average price of a steer was N35,000 while that of a cow was N30,000. This shows an increase of 313\% for steers and $152 \%$ for the cows which indicated that, the former fetches more money than the latter.

\section{CONCLUSION}

In relation to human population, there is now the tendency for a shortage of cattle population per se, since within recent years human population have grown faster than cattle population. However, the major constraint to sufficient supply of beef is the low carcass quality of Nigerian cattle. Breeds of Nigerian cattle, in common with others indigenous to Africa, grow slowly, taking three to four years to reach sexual maturity and attain slaughter weight, with a dressing percentage of between 50 and 55 . The calving intervals take from eighteen to twenty four months; calving rate is put at 53\% (Oyenuga, 1982). They are slow converters of vegetable feeds into animal products. High calf mortality of up to $20 \%$, cow culling rates of $10 \%$ with a replacement rate of $15 \%$. Cow to bull ratio is usually high, making only a small proportion of younger bulls available for slaughter. Cow slaughter weight of the larger breeds average $250 \mathrm{~kg}$.

\section{RECOMMENDATIONS}

The cattle industry should now and in the near future call for modern profit oriented business enterprising with the injection of large capital outlay to minimize, by $2000 \mathrm{AD}$, the huge amount of money which would have been spent on foreign exchange for massive beef importation. The objective must be in each herd to select more productive breeds with lower calving age, higher calving frequencies, increased number of mature females with a maximum calf-crop per annum. Reduction of mortality in all age groups in the herd particularly in the young animals, thus rapidly building up the number in the herd and thereby improving the annual off-take rates and carcass weights. Such farms must develop the strategy for improving the proportion of fodder and feed used for maintenance and production in order to improve the overall feed efficiency. Improved range management, water supplies and disease control are essential ingredients for modern cattle production.

\section{REFERENCES}

[1] Abubakar, I. A., \& Garba, H. S. (2004). A Study of Traditional Methods for Control of Ticks in Sokoto State, Nigeria. Proceedings of the 29th Annual Conference of the Nigerian Society for Animal Production, 29, 87-88.

[2] Adegeye, A. J. (1995). Statistical Analysis of Demand for Beef in the Western State of Nigeria. Bulletin of Rural Economics and Development, 6 (1), 70-75.

[3] Adegeye, A. J., \& Dittoh, J. S. (1985). Essentials of Agricultural Economics. Impact Publishers Nigeria Limited, Ibadan.

[4] Adisa, R. S., \& Badmos, A. H. A. (2009). Socioeconomic correlates of perceptions of sustainability of pastoral livelihood among cattle herdsmen in Kwara state, Nigeria. Agrosearch, 10 (1and2), 21 - 30. 
[5] AFRIS (2010). Animal Feed Resources Information System. file://C: Documents $\% 20$ and \%20 Setting/ADMIN/My\% Document. Retrieved 26/7/2014.

[6] Agboola, S. A. (1979). An Agricultural Atlas of Nigeria. First Edition, Oxford University Press Limited, London, pp. 153-156.

[7] Ajiya, K. (1998). Student Final Year Project. Department of Agricultural Economics and Extension. Federal University of Technology Yola. Unpublished.

[8] Akinwumi, J. A., \& Ikpi, A. E. (1985). Trypanotolerant cattle production in Southern Nigeria. Report to International Livestock Centre for Africa (ILCA) Humid Programme, Ibadan, pp. 101 258.

[9] Akinwumi, J. A. (1986). The Nigerian Livestock Industry (Problems and Prospects). A Proceeding of Workshop on the Proposed Sub-Livestock Sector Review Held in Jos, 26th - 27th February, 1986.

[10] Akpa, G. N., Alphonsus, C., \& Abdulkareem, A. (2012). Evaluation of herd structure of white Fulani cattle holdings in Zaria, Nigeria. Scientific Research and Essays, 7 (42), 3605 - 3608.

[11] Alphonsus, C., Akpa, G. N., Barje, P. P., Finangwai, H. I., \& Adamu, B. D. (2012). Comparative evaluation of linear udder and body conformation traits of bunaji and friesian $\mathrm{x}$ bunaji cows. World Journal of Life Science and Medical Research, 2 (4), 134 - 140.

[12] Angassa, A., \& Oba, G. (2007). Relating long-term rainfall variability to cattle population dynamics in communal rangelands and a government ranch in southern Ethiopia. Agric. Syst., 94, $715-725$.

[13] Auwal, A. (2005). Political Decisions in Nigerian Agricultural Industry. Journal of Applied Sciences and Management, 2, 186.

[14] Babayemi, O. J., Abu, O. A., \& Opakunbi, A. (2014). Integrated animal husbandry for schools and colleges, First edition. Positive Press Ibadan, Nigeria, pp. 20 - 122.

[15] Barje, P. P., Adebayo, J. H., \& Lamidi, O. S. (2011). Comparative evaluation of groundnut haulms and lablab (lablab purpureus) as dry season supplements for lactating cows and their calves under smallholder peri-urban dairy production in Nigeria. Savannah Journal of Agriculture, 6 (2), 1 -5.

[16] Bénard, C., Bonnet, B., \& Guivert, B. (2010). Demand for farm animal products in Nigeria: An opportunity for Sahel countries? Grain de Sel, 51, 14 - 15.

[17] Blench, R. M. (1993). Ethnographic and linguistic evidence for the prehistory of African ruminant livestock, horses and ponies. The Archaeology of African Food, Metals and Towns, pp. $71-103$.

[18] Blench, R. M., De Jode, A., Gherzi, E., \& Di Domenico, C. (1998). Keteku and Ndama crossbred cattle in Nigeria: History, distribution and productivity. In C. Seignobos and E. ThysParis (Ed.) Des Taurins au Cameroun et Nigeria.: ORSTOM/IEMVT, Maisons-Alfort, pp. 293-310.

[19] Blezinger, B. S. (2008). Age at puberty and scrotal circumference are important factors for bull selection. In cattle today. USA, Kansas Publishers limited.

[20] CBN (1999). Annual Report of Central Bank of Nigeria, 10, 41.

[21] Chimonyo, M., Kusina, N. T., Hamudikuwanda, H., \& Nyoni, O. (2000). Effect of work stress and supplementary feeding on body conformation, ovary activity and blood parameters in a smallholder farming system. Asian-Australian Journal of Animal Science, 13 (8), 1054 -1058.

[22] Cunnings, I. (1966). Baggara Arabs. Oxford University Press, London.

[23] DelCurto, T., Hess, B. W., Huston, J. E., \& Olson, K. C. (2000). Optimum supplementation strategies for beef cattle consuming low-quality roughages. Journal of Animal Science, 77, 1-16.

[24] Delgado, C., Rosegrant, M., Steinfeld, H., Ehui, S., \& Courbois, C. (1999). Livestock to 2020: The next food revolution 2020. Food, Agriculture and the Environment Discussion Paper 28. IFPRI/FAO/ILRI, pp. 25 - 70.

[25] Devendra, C., \& Sevilla, C. C. (2002). Availability and use of feed resources in crop-animal systems in Asia. Agric. Syst., 71 (1-2), 59 - 73. 
[26] du Plessis, I., \& Hoffman, L. C. (2004). Effect of chronological age of beef steers of different maturity types on their growth and carcass characteristics when finished on natural pastures in the arid sub-tropics of South Africa. South African Journal of Animal Science, 34 (1), 1-12.

[27] FAO. (1990). Production Year Book. Rome, Italy, 46, 153.

[28] FAO (1996). World development report paper no. 2. Food and Agricultural Organization, Rome, Italy.

[29] FAO (1997). integrating crops and livestock in West Africa.Animal production health paper No.43, Food and Agricultural Organization, Rome, Italy.

[30] FAO (1999).Global strategy for the management of farm animal genetic resources.executive briefing. Food and Agricultural Organization, Rome, Italy.

[31] FAO. (2006). Trypanotolerant Cattle and Livestock Development in West and Central Africa. Animal Production Health Paper, 2, 213-230.

[32] Filani, M. O. (2006). Transport Market Study- The Bodija Cattle Market in Ibadan. Department of Geography University of Ibadan, Nigeria.

[33] Gandhi, M. (2009). Uses of animal fats in cosmetics industries. The Bihar Times, pp. 22 - 35.

[34] Gates, G. M. (1952). Breeds of cattle found in Nigeria. Farm and Forest, 11, 19 - 43.

[35] Girei, A. A., Dire, B., \& Bello, B. H. (2013). Assessment of cost and returns of cattle marketing in central zone of Adamawa state, Nigeria. British Journal of Marketing Studies, 1 (4), 1-10.

[36] Gohl, B. (1981). Tropical feeds: Feed information summaries and nutritive value. Animal Production Series, FAO, Rome, Italy.

[37] Ifeanyi, A. O., \& Olayode, G. O. (2008). Analysis of trends in livestock production in Nigeria from 1970-2005. Journal of Agriculture and Social Research (Jasr), 8 (1), 114 - 120.

[38] ILCA (1979). Trypanotolerant livestock in West and Central Africa. Addis Ababa. ILCA Monograph, 2(2), 241 - 340.

[39] Iro, I. S. (1994). The Fulani herding system. African Development Foundation, Washington.

[40] Iro, I. S. (2009). Fulani herding system. Data analyst in Washington, DC. USA.

[41] Jahake, H. E. (1992). Livestock production systems and livestock development in tropical Africa: In Kieler Wiscenchaftsverlag Vauk, pp. 72 - 74.

[42] Katie, T., \& Alistair, F. (1986). The complete book of raising livestock and poultry-A small holder's guide. University Services Ltd., Yaba Lagos.

[43] Ken, G. (1982). Opening Address, by the Honourable Minister of State for Agriculture. Proceedings of the National Conference on Beef Production held at NAPRI Shika, A.B.U. Zaria, pp. $6-11$.

[44] Knowlton, P.H., Hoover, W. H., Sniffen, C.J., Thompson, C. S., \& Belyea, P. C. (1976). Hydrolized leather scraps as a protein source for ruminants. Journal of Animal Science, 43, 1095-1103.

[45] Kohls, R. L., \& Uhl, J. N. (1985). Marketing of Agricultural Products. Sixth Edition, McMillan Publishers Company, New York, pp. 5 - 8.

[46] Kohls, R. L., \& Uhl, J. N. (2002). Marketing of agricultural products, 9th Ed, Prentice-Hall McMillan Publishers Company, New York.

[47] Kubkomawa, H. I., Helen, U. O., Timon, F., Kabir, A. M., \& Neils, S. J. (2011). The use of camels, donkeys and oxen for post emergence weeding of farm lands in North-Eastern Nigeria. Journal of Agriculture and Social Sciences, 7(4), 136 - 138.

[48] Liu, D. C. (2009). Better utilization of by-products from the meat industry. Department of Animal Science. National Chung-Hising University Taichung Taiwan.

[49] Mafimisebi, T. E. (2011). Spatial Price Equilibrium and Fish Market Integration in Nigeria: Pricing Contacts of Spatially Separated Markets. LAP Lambert Publishing Company, Germany. pp. 157.

[50] Mafimisebi, T. E. (2012). Spatial Equilibrium, Market Integration and Price Exogeneity in Dry Fish Marketing in Nigeria: A Vector Auto-regressive (VAR) Approach. Journal of Economics, Finance and Administrative Sciences, 17 (33), 31-37. 
[51] Mafimisebi, T. E., \& Okunmadewa, F. Y. (2006). Are Middlemen Really Exploitative? Empirical Evidence from the Sun-dried Fish Market in Southwest, Nigeria. In: Re-building Fisheries in an Uncertain Environment, CD-ROM of the 13th Biennial Conference of the International Institute of Fisheries Economics and Trade. P. I2.

[52] Mafimisebi, T. E., Bobola, O. M., \& Mafimisebi, O. E. (2013). Fundamentals of Cattle Marketing in Southwest, Nigeria: Analyzing Market Intermediaries, Price Formation and Yield Performance. Paper presented at the 4th International Conference of the African Association of Agricultural Economists, held in Hammamet, Tunisia from September 22-25, 2013.

[53] Mafimisebi, T. E., Oguntade, A. E., Fajeminsin, N. A., \& Ayelari P. O. (2012). Local Knowledge and Socio Economic Determinants of Traditional Medicines' Utilization in Livestock Health Managements in South West Nigeria. Journal of Ethnobiology and Ethno medicine, January 2012

[54] Mapiye, C., Chimonyo, M., \& Dzama, K. (2009).Seasonal dynamics, production potential and efficiency of cattle in the sweet and sour communal rangelands in South Africa. Journal of Arid Environ., 73(4), 529-536.

[55] Mbanasor, J.A. (2000). The future of livestock in Nigeria. In S.N. Ukachukwu, J.A., Ibe, S.N. Ibeawuchi, A.G. Ezekwe and S.F. Abasiekong (Ed.) Animal production in the new millennium challenges and options, proceedings of the 25th animal conference held at the Michael Okpara University of Agriculture Umudike, Nigeria, March 2000, pp. 8 - 16.

[56] Mbap, S. T. (1996). A note on heritability estimates of birth weight and calving interval of white Fulani cattle. Nigerian Journal of Animal Production, 23(122), 101-102.

[57] Meghen, C., MacHugh, D. E., Sauveroche, B., Kana, G., \& Bradley, D. G. (1999). Characterization of the Kuri Cattle of Lake Chad using Molecular Genetic Techniques. In R. M. Blench and K.C. MacDonald (Ed.) The origin and development of African livestock. University College Press, London, pp. 28 - 86.

[58] Miles, R. D., \& Jacob, J. P. (2009). Using meat and bone meal in poultry diet. University of Florida IFAS Extension Document PS28, USA.

[59] Mohammed, G., Igwebuike, J. U., \& Kwari I. D. (2005). Performance of growing rabbit fed graded level of goat rumen content. Global Journal of Pure and Applied Science, 11(1), 39 - 43.

[60] Mubi, A. A., Michika, S. A., \& Midau, A. (2012). Cattle marketing in Mubi Area of Adamawa State, Nigeria. Agric. Biol. Journal of North America, 4(3), 199 - 204.

[61] Ndlovu, T., Chimonyo, M., \& Muchenje, V. (2009). Monthly changes in body condition scores and internal parasite prevalence in Nguni, bonsmara and Angus steers raised on sweet veld. Trop. Anim. Health Prod., 41(7), 1169 - 1177.

[62] Newman, J. A., Thompson, W. A., Penning, P. D., \& Mayes, R. W. (1990). Least-squares estimation of diet composition-from nalkanes in herbage and faeces using matrix mathematics. Australian Journal of Agric. Res., 46, 793 - 805.

[63] NLPD (1992). Nigerian National Livestock Project Division. Survey in Kaduna, Nigeria, 58, 175 $-177$.

[64] NNLRS (1990). Nigerian national livestock resource survey, pp. 627 - 649.

[65] Nqeno, N., Chimonyo, M., Mapiye, C., \& Marufu, M. C. (2009). Ovarian activity, conception and pregnancy patterns of cows in the semi-arid communal rangelands in the Eastern Cape Province of South Africa. Anim. Reprod. Sci., 23, 18 - 48.

[66] Okoli, I. C., Ebere, C. S., Emenalom, O. O., Uchegbu, M. C., \& Esonu, B. O. (2001). Indigenous livestock production paradigms revisited. 111: An assessment of the proximate values of most preferred indigenous browses of Southeastern Nigeria. Anim. Prod. Invest., 4, 99-107.

[67] Okoli I. C., Enyinnia N. C., Elijah A. G., Omede A. A., \& Unamba-Opara C. I. (2012). Animal reproductive management practices of Fulani pastoralists in the humid rain forest of Imo State, Nigeria. Journal of Animal Science Advances, 2(2), 221- 225.

[68] Olaloku, E. A., \& Debre, S. (1992). Research priorities for the development of appropriate feeding systems for dairy production in sub-saharan Africa. In J. E. S. Stares, A. N. Said and J. A. Kategile (Ed) The complementarity of feed resources for animal production in Africa. 
Proceedings of the Joint Feed Resources Networks Workshop held in Gaborone, Botswana, $4^{\text {th }}$ to $8^{\text {th }}$ March 1991.African Feed Research Network. ILCA, Addis Ababa, Ethiopia, pp. 399.

[69] Ologun, A, G. (1980). Seasonal and breeding variations in birth weight and age at first calving of exotic, local and crossbred cattle in a Tropical environment. Journal Anim. Sci., 51(1), 153.

[70] Olomu, J. M. (1995). Monogastric animal nutrition. principles and practice. A Jachem Publication, Benin City, Nigeria.

[71] Okunmadewa, F. Y. (1999). Livestock Industry as a Tool for Poverty Alleviation. Tropical Journal of Animal Science, 2(2), 21-30.

[72] Omoruyi, S. A., Orhue, U., Akerobo, A. A., \& Aghimien, C. I. (2000). Prescribed Agricultural Science for Secondary Schools; Benin City, Idodo Umeh Publishers Ltd. Pp. 443- 445.

[73] Oyenuga, V. A. (1982). Future of the Beef Industry in Nigeria. In Osinowo, O. A., Ikhatua, U. J. and Ehoche, W. O. (eds). Proceedings of the National Conference on Beef Production held at Durbar Hotel Kaduna, pp. 58 - 69.

[74] Pagot. J. (1992). Animal production in the tropics and subtropics. Macmillan Press Ltd. London and Basingstoke,

[75] Payne, W.J.A., \& Wilson, R.T. (1999). Animal husbandry in the tropics, 5th edt. Blackwell Science, Oxford, UK.

[76] Poppi, D. P., \& McLennan, S. J. (1995). Protein and energy utilization by ruminants at pasture. Journal of Animal Science, 73, 278- 290.

[77] RIM, (1992). Nigerian national livestock resource survey (IV). Report by resource inventory and management limited (RIM) to FDL and PCS, Abuja, Nigeria.

[78] Schutz, P. (1995). Agricultural Economics For Tropical Africa, London: Heinemann, p. 86.

[79] Seperich, G. J., Woolverton, M. W., \& Beirlein, J. G. (2002). Introduction to Agribusiness Marketing, Prentice Hall, Pearson Education Company, Upper River.

[80] Shabi, Z., Arieli, A., Bruckental, I., Aharoni, Y., Zamwel, S., Bor, A., \& Tagari, H. (1998). Effect of the synchronization of the degradation of dietary crude protein and organic matter and feeding frequency on ruminal fermentation and flow of digesta in the abomasum of dairy cows. Journal of Dairy Sci., 81, 1991 - 2000.

[81] Starkey, P. H. (1984). N'Dama cattle - a productive trypanotolerant breed. World Animal Review, 50, 2 - 15.

[82] Swinton, S. (1987). Drought survival tactics of subsistence farmers in Niger. Human Ecology, 1(2), 108 - 122.

[83] Synge, B. (1980). Factors limiting cattle productivity in highland areas of Nigeria. Centre for Tropical Veterinary Medicine, Easter Bush, Roslin, Midiothian, Scotland.

[84] Tainton, N. M. (1999). Veld management in South Africa. University of Natal Press, Pietermaritzburg, South Africa.

[85] Tibi, K. N., \& Aphunu, A. (2010). Analysis of Cattle Market in Delta State: The Supply Determinants. African Journal of General Agriculture, 6 (4), 199-203.

[86] Tukur, H. M., \& Maigandi, S. A. (1999). Studies on Animal Traction in Northeastern Nigeria: Characterization and Management of Animals used For Draught. Tropical Journal of Animal Science, 1(1), 10-27.

[87] Umar, A. S. S. (2007). Financial analysis of small scale beef fattening enterprise in bama local government area of Borno state. M.Sc. Thesis, Ahmadu Bello University, Zaria, Nigeria.

[88] Umar, A. S., Alamu, J. F., \& Adeniyi, O. B. (2008). Economic Analysis of Small-scale Cow Fattening Enterprise in Bama Local Government of Borno State, Nigeria.

[89] USDA (1993). Livestock by- product and seafood wastes contain valuable ingredients. US Department of Agriculture, Washington DC.

[90] Usman, H., \& Nasiru, M. (2005). Commodity chain analysis of cattle marketing in Nigeria; A case study of K.R.I.P area Kano state. A report submitted to ADENI project/NAERLS Zaria, Nigeria. 
[91] Von Kaufmann, R. (1986). The Establishment and Management of Fodder Banks. In Livestock Systems Research in Nigeria's Sub humid Zone Proceedings of a second I.L.C.A. /N.A.P.R.I. Symposium held in Kaduna, Nigeria, p. 326.

[92] Wakili, B. A. (1986). Connection and Profit Margin of Cattle marketing in Maiduguri. Student Final Year Project. Department of Agricultural Economics and Extension. University of Maiduguri, unpublished.

[93] Whitley, E. (2008). Cow café: The importance of breeding soundness examination in www.cattlenetwork.com. Retrieved 2nd July, 2016.

[94] Williamson, G., \& Payne, W. J. A. (1990). An introduction to animal husbandry in the tropics. Longman Group, London. 